\title{
LEGĂTURA VIE \\ DINTRE ÎNVĂȚĂTURA BISERICII ŞI PRACTICA \\ PASTORALĂ. REPERE DIN EXPERIENȚA \\ PASTORAL-MISIONARĂ \\ A CLERULUI ŞI CREDINCIOŞILOR ORTODOCŞI \\ GRECI
}

Ion Marian Croitoru*

\begin{abstract}
The phenomenon of occidentalization and secularization leads to an increasing reconsideration of the role of the parish in the contemporary society. Perceived as the living cell of the Church, along with the monastery and the family, the parish represents the Eucharistic assembly in which the believer lives the quality of limb of Christ's Body, fully participating in the Mystery of the Church as a whole. For this reason, life in a parish takes place both vertically, on the level of man's union with God, and horizontally, accomplishing the communion and brotherhood with our fellows, in all the dimensions of the spiritual and sociopolitical life, such as: the relations between clergy and believers, the realization of the aim of the parish, the cultivation of the relations between parish and monastery, but also the attachment to the Holy Fathers, the participation to the divine service, and, in the light of this participation, the contribution to the sociopolitical life of our fellows, accomplishing in this way the living connection between the teaching of the Church and pastoral practice. All these dimensions are analyzed, under different aspects, in the present study, based on the experience of the clergy and of the believers of the Christian Orthodox Church in Greece.
\end{abstract}

Keywords: parish, monastery, man's deification, spiritual life, states of purification, illumination and deification, society, political life, Divine Eucharist, occidentalization, secularization.

$\mathrm{PhD}$, Assistant Professor, "Valahia" University, Faculty of Orthodox Theology, Târgovişte, Romania. 
Expunerea acestui referat în cadrul celei de a XIV-a ediții a Simpozionului Internațional de Ştiință, Teologie şi Arte (ISSTA 2015), eveniment organizat în sediul Facultăţii de Teologie Ortodoxă din Alba Iulia, în perioada 4-6 mai, 2015, constituie rezultatul unui studiu mai amplu, având ca temă generală gândirea şi viziunea teologică a grecilor ortodocşi contemporani asupra parohiei, precum şi aplicarea învăţăturii Bisericii Ortodoxe în viaţa credincioşilor. Din motive obiective, timpul acordat expunerii unui referat este limitat, dar şi spațiul consacrat editării fiecărei lucrări în parte, astfel că am ales ca o primă parte a acestui studiu să fie prezentat la Simpozionul Internaţional „Misiune şi propovăduire. 150 de ani de la întemeierea Episcopiei Caransebeşului (20-21 aprilie 2015)", desfãşurat la Caransebeş, cu ocazia manifestărilor culturale închinate împlinirii a 150 de ani de la înființarea Episcopiei Ortodoxe a Caransebeşului şi a organizării ediției a IX-a a „Zilelor credinței şi culturii” în această Episcopie (19-26 aprilie). În referatul prezentat pentru acea ocazie, cu titlul Misiunea parohiei în lumea contemporană. Sensul parohiei şi scopul ei din perspectiva gândirii teologice ortodoxe grecești, am cuprins aspecte referitoare la: 1) definirea unui concept: parohia; 2) raportul dintre cler şi credincioşi; 3) scopul parohiei; şi 4) legătura dintre parohie şi mănăstire. Aceste aspecte reprezintă doar o parte din gândirea şi viziunea teologică a grecilor ortodocşi asupra rolului parohiei în societatea contemporană, reflectate prin experiența pastoral-misionară a Bisericii Ortodoxe din Grecia, pe care le completez în referatul expus la prezentul Simpozion Internațional, subliniind următoarele puncte: 1) parohia şi Sfinții Părinți; 2) parohia şi cultul Bisericii; 3) parohia şi societatea; şi 4) legătura vie dintre învățătura Bisericii şi practica pastorală.

\section{Parohia şi Sfinții Părinți}

Ceea ce dă stabilitate vieții unei parohii, mai ales când preoții au o viziune lumească asupra comunității parohiale, iar prin acțiunile lor sunt în afara Sfintei Tradiții a Bisericii, este ataşamentul credincioşilor față de cuvântul Sfinților Părinți. În felul acesta, 
conform Părintelui Gheorghe Metallinos, Sfinții Părinți devin „duhovnicii şi învățătorii credincioşilor, iar cuvântul lor se aude din cărțile liturgice, imne şi rugăciuni”. Aşadar, cuvântul Sfinților Părinți devine o hrană zilnică pentru cei ce participă la cultul liturgic al parohiei, care cuvânt li „,se oferă ca rugăciune şi imn latreutic”. „Numai dacă va tăcea cuvântul scripturistic (profetic şi apostolic) şi patristic, atunci există pericolul să se piardă orientarea dreaptă şi ținta vieții bisericeşti"”.

Sfântul Grigorie Teologul arată cât de mare este rolul păstorului tămăduitor sau, cu alte cuvinte, al preotului mărturisitor ${ }^{2}$ : „trebuie să fie curat, apoi să curețe; să fie înțelepțit şi aşa să înțelepțească; să devină lumină şi să lumineze; să se apropie de Dumnezeu şi să-i aducă şi pe alții; să fie sfințit şi să sfințească; să conducă cu mâinile, să sfătuiască cu pricepere"3. Sfântul Ioan Gură de Aur afirmă că „Dumnezeu nu hirotoneşte pe toți, pe de o parte, iar pe de altă parte, El lucrează prin toți’”4.

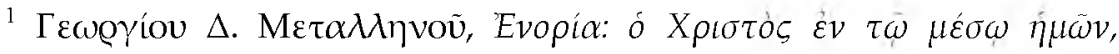

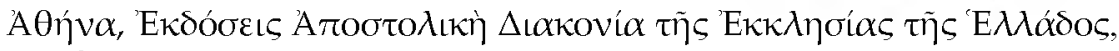

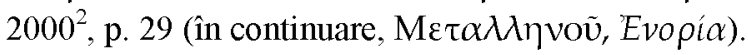

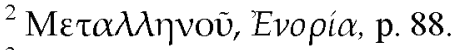

${ }^{3}$ Sfântul Grigorie Teologul, Cuvântul al II-lea apologetic din cauza fugii în Pont, 71, în Patrologiae cursus completus, Series graeca (în continuare, PG)

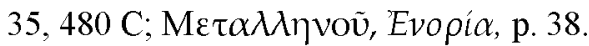

${ }^{4}$ Sfântul Ioan Gură de Aur, Omilia a II-a la Epistola a II-a către Timotei, 3, în

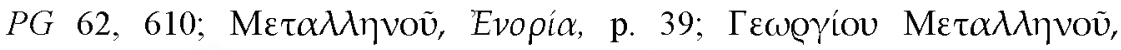

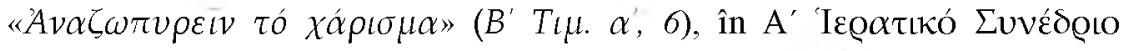

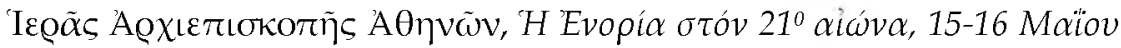

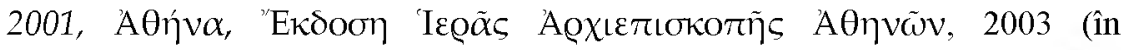

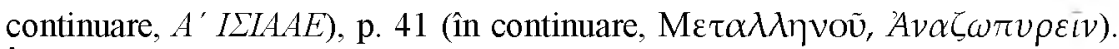
În fiecare epocă, Sfinții Părinţi atrag atenția asupra căderii din harul preoției. De pildă, Sfântul Nicodim preia cuvintele Sfântului Isidor Pelusiotul din secolul al V-lea şi afirmă că demnitatea preoției a decăzut, chiar din timpul acela, în tiranie, de la smerenie în mândrie, de la post în desfătare, de la

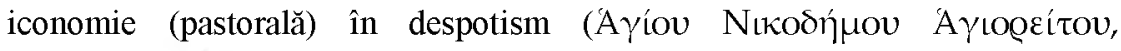

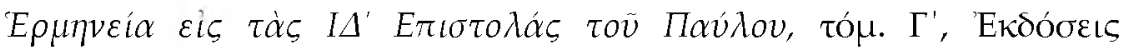


Lipsurile cât priveşte viața duhovnicească sunt umplute doar prin luarea aminte cu smerenie la „cuvântul şi fapta Sfinților Părinți”, ascultându-le şi înfăptuindu-le 5 . Dacă un cleric „,̂i lasă pe Sfinţii Părinți să fie călăuze în slujirea sa, atunci dobândeşte şi propria sa lucrare un caracter patristic, adică bisericesc" ${ }^{\text {"6 }}$. Predica neîntreruptă a Sfinților Părinți se referă la desăvârşirea credinciosului prin comuniunea în Hristos cu frații săi. În felul acesta, preotul are posibilitatea să conştientizeze adevărul că integrarea credincioşilor în Trupul lui Hristos reprezintă premisă a mântuirii lor, deoarece parohia este pentru fiecare credincios locul mântuirii sale, un loc în care învață să trăiască în comuniunea cu Hristos şi cu frații săi întru Hristos $^{7}$, adică un loc în care dobândeşte modul de viață conform căruia ajunge la îndumnezeire, cu alte cuvinte, la mântuirea sa în Trupul cel unul al Bisericii ${ }^{8}$.

În faţa sistemelor ideologice şi a mişcărilor politice, parohia, înțelegând prin ea pe preot şi enoriaşii săi, este datoare să meargă „pe urmele Sfinților, urmând propria lor cale, din moment ce doar aceasta conduce la îndumnezeire" ". Acest fapt înseamnă că fiecare credincios este chemat să se încadreze cu totul în Sfânta Tradiție a Bisericii, dar pentru a înfăptui acest lucru se cuvine ca el să cunoască „cuvântul Tradiției (adică Teologia Bisericii)", precum şi să învețe modul de trăire în această Tradiție, adică viața duhovnicească. „Una dintre cele mai grave lipsuri ale credincioşilor, astăzi, este că şi cei ce vin la Biserică, în mod regulat, arareori cunosc duhul Tradiției şi, din acest motiv, nu pot să trăiască în conformitate cu acesta. Cunoştințele lor din spaţiul Tradiţiei sunt adesea amestecate cu diferite superstiţii şi rătăciri şi concepții necreştine. De aceea şi atât de adesea ei arată o neputință

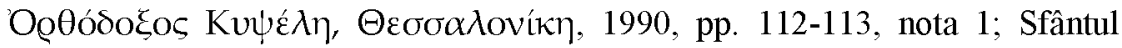
Isidor Pelusiotul, Epistolar, Cartea a III-a, Epistola a CCXXIII-a, în PG 78,

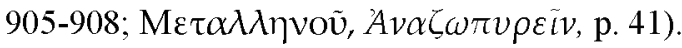

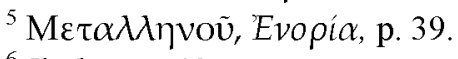

${ }^{6}$ Ibidem, p. 40.

${ }^{7}$ Ibidem, p. 57.

${ }^{8}$ Ibidem, p. 57.

${ }^{9}$ Ibidem, p. 78 . 
impardonabilă de a percepe unele problematizări care privesc Biserica, fiindcă reflexele lor duhovniceşti nu pot să reacționeze"10.

Sfânta Tradiție se află nealterată la Sfinții Părinți şi în cultul Bisericii, dar este nevoie de cheile potrivite pentru cercetarea şi înțelegerea corectă atât a Sfinților Părinți, cât şi a cultului Bisericii. Aceste chei le poate da cel vindecat duhovniceşte, adică cel ce este o călăuză experimentată, cu alte cuvinte, Părintele duhovnic ajuns la măsura desăvârşirii duhovniceşti. Fără aceste chei de interpretare există pericolul ca Sfinții Părinți să fie citiți şi percepuţi printr-o metodă străină de modul lor de trăire şi cugetare, astfel că nu mai sunt percepuți ca purtători ai vieții şi ai experierii de luminare şi de îndumnezeire, ci ca exponenți ai unor filosofii sau sisteme filosofice ${ }^{11}$. Dar şi Sfânta Tradiție în sine nu mai este interpretată corect, ci transformată din „mişcare şi viață" în forme de conservatorism $^{12}$. Evitarea acestei transformări negative se realizează în măsura în care credincioşii devin tot mai mult ataşaţi Sfintei Tradiţiei şi trăiesc tot mai mult în mod liturgic Sfânta Tradiţie, astfel că viața parohiei este cu atât mult mai vie ${ }^{13}$.

Prin urmare, numai pe baza experierii Sfinților Părinți, care sunt clerici şi mireni de diferite categorii sociale şi pregătiri intelectuale, din toate timpurile Bisericii şi inclusiv până în vremurile noastre, este conştientizat faptul că principalul scop al parohiei nu este acela de a săvârşi ,,pur şi simplu o lucrare socială şi filantropică” sau de a se epuiza „în «slujbe» şi «hramuri» sau înregistrări de stări

\footnotetext{
${ }^{10}$ Ibidem, pp. $140-141$.

${ }^{11}$ Ibidem, p. 193.

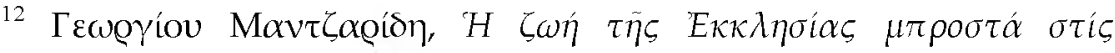

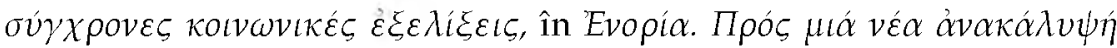

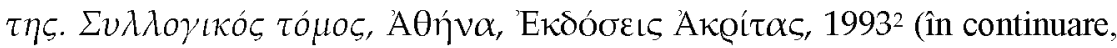

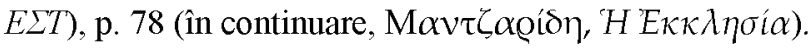

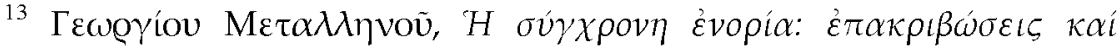

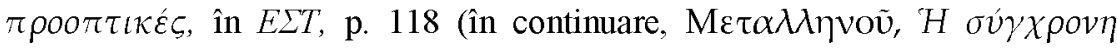
غेvopía).
} 
civile $^{14}$, ci să fie un viu şi activ «laborator» de mântuire îndumnezeire. Să fie o arenă de luptă împotriva oricărui fel de înşelare, a morții, a păcatului, a stricăciunii şi cristelniță a naşterii din nou şi a învierii. Lucrarea socială (filantropică) va fi atunci încadrată în lupta mântuirii - îndumnezeirii, iar sociabilitatea şi frăţietatea vor fi roade fireşti ale comuniunii cu harul dumnezeiesc necreat" ${ }^{\text {"15 }}$.

Nu se cuvine ca Sfinții Părinți să fie copiați sau urmați într-un mod exterior ${ }^{16}$, ci trebuie să ne raportăm prin propria noastră trăire la

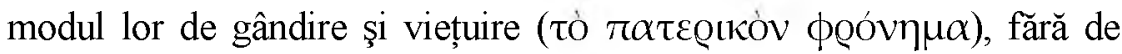
care nu poate să fie percepută conştiința ortodoxă şi, în consecință, este imposibil să se obțină eliberarea de confuzia în care se află cei ce au primit Botezul «cel unul» al lui Hristos, adică de amalgamul curentelor şi prejudecăţilor alimentate de duhul lumesc şi diferite mentalități izvorâte din acesta, care conduc la slăbirea reflexelor duhovniceşti şi a criteriilor patristice ${ }^{17}$. Fiecare creştin care a primit Botezul «cel unul» este chemat ca să ajungă, prin harul lui Dumnezeu, Părinte al propriei sale epoci ${ }^{18}$, pentru că în acest mod Biserica păşeşte în istorie.

\section{Parohia şi cultul Bisericii}

Dumnezeiasca Euharistie reprezintă epicentrul cultului Bisericii, după cum Sfântul Altar reprezintă centrul parohiei, iar săvârşirea Dumnezeieştii Euharistii în parohie, în cadrul Dumnezeieştii Liturghii, conferă credincioşilor comuniunea cu Iisus Hristos, prin împărtăşirea cu Trupul şi Sângele Său. Prin Dumnezeiasca Euharistie, unirea credinciosului cu Hristos nu este

\footnotetext{
${ }^{14}$ Reamintesc că în Grecia cununiile oficiate la Biserică au şi valoarea actelor de stare civilă.

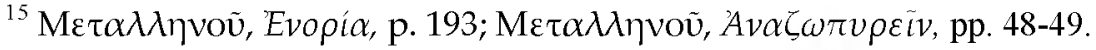

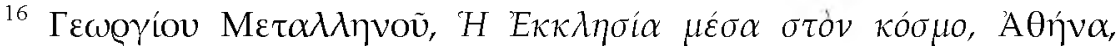

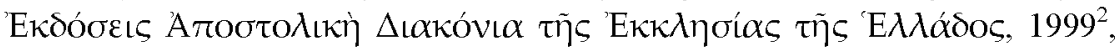

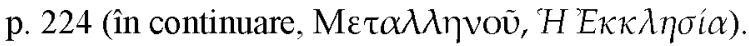

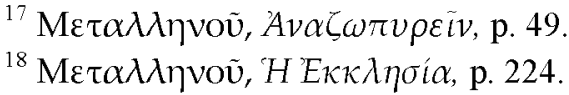


doar pe verticală, ci şi pe orizontală, cu toți cei ce participă şi se împărtăşesc din acelaşi Sfânt Potir, încât comuniunea cu Dumnezeu devine din manifestare individuală una bisericească ${ }^{19}$, fiindcă Dumnezeiasca Euharistie reprezintă „exprimarea Bisericii ca trup al lui Hristos" ${ }^{\prime 2}$. În acest fel, Dumnezeiasca Euharistie caracterizează parohia şi viaţa ei şi le reînnoieşte permanent ${ }^{21}$, pentru că prin ea se lucrează ajungerea fiecărui membru al ei în starea de dumnezeu-om după har, făcându-l membru al Trupului Domnului. De aceea, adunarea credincioşilor are un caracter „liturgic" şi „euharistic”, care indică şi mişcarea permanentă a credincioşilor spre realizarea existenței lor eshatologice ${ }^{22}$.

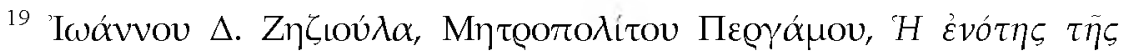

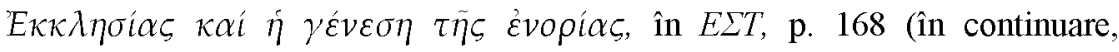

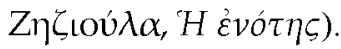

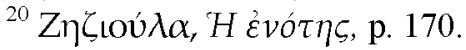

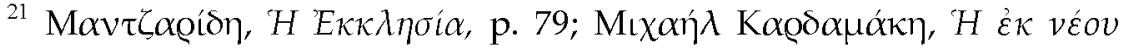

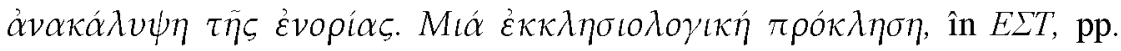

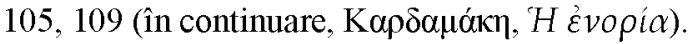

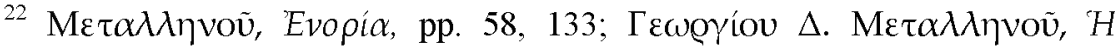

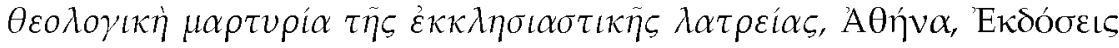
AQuós, 1995, p. 217. Biserica nu poate să fie împărțită în Biserica

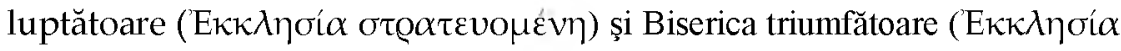
$\theta \varrho \iota \alpha \mu \beta \varepsilon v ́ o v \sigma \alpha)$, pentru faptul că membrii ei care sunt luptători, participă încă din această viață la eshaton, pregustă Împărătia lui Dumnezeu și, ,,de aceea, din viața prezentă încep să triumfe, adică au începutul slavei lui Dumnezeu"

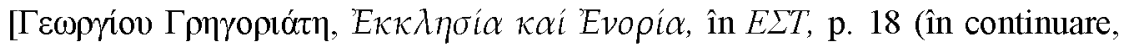

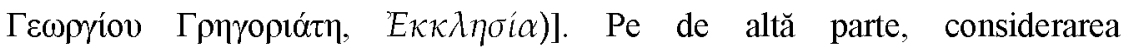
Dumnezeieştii Euharistii ca „una dintre cele şapte Taine” ale Bisericii reprezintă influență scolastică în învățătura ortodoxă, deoarece Dumnezeiasca Euharistie nu este ,un mijloc printre altele spre mântuirea omului", ci „descoperirea Bisericii însăși” și „exprimarea în sine a mântuirii, care

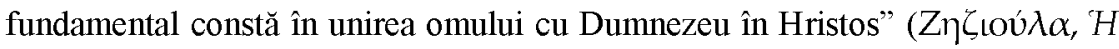

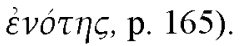


Viaţa zilnică a credincioşilor se poate raporta la ciclul slujbelor dintr-o zi liturgică, care are ca scop transformarea duhovnicească a omului. Prin urmare, „cultul nu a fost niciodată pentru Biserică o ipoteză «spiritualistă »şi idealistă sau o simplă adunare religioasă, aşa cum este perceput astăzi, din cauza denaturării caracterului său, cu trecerea veacurilor” ${ }^{\prime 23}$. Din contră, participarea „poporului lui Dumnezeu” la Dumnezeiasca Euharistie „nu reprezintă o ipoteză privată a fiecărui credincios", ci realizarea comuniunii în Hristos cu toți ceilalți membrii ai parohiei, pentru că prin Potirul comun cei înainte străini devin fraţi în Hristos, contribuindu-se la zidirea Trupului Bisericii la nivelul parohiei respective, în cadrul căruia omul este chemat să trăiască taina mântuirii sale ${ }^{24}$.

„Bun creştin” este cel ce este viu, adică cel ce participă la Dumnezeiasca Euharistie în mod activ şi nu pasiv, adică se pregăteşte cu intensitate pentru împărtăşirea cât mai deasă cu Trupul şi Sângele lui Hristos, din această poziție luând parte şi la celelalte forme ale cultului Bisericii ${ }^{25}$. Prin această conştientizare şi participare activă, cultul este continuat şi în afara locaşului de cult, astfel încât, trăindu-se «liturghia după liturghie» ${ }^{26}$, toată viața credincioşilor să fie transformată în adorarea lui Dumnezeu. Însă, pentru menținerea adevăratei vieți duhovniceşti, s-a născut în cadrul cultului Bisericii «dreptul canonic», întregit în adunările Sfinților Părinţi şi în Sinoadele Ecumenice şi locale. „Sfintele canoane, care trasează limitele vieții în Hristos, acoperă toate legăturile interpersonale duhovniceşti şi vitale"27. De pildă, cât priveşte participarea la Dumnezeiasca Liturghie, prin sfintele canoane se arată că această participare este o condiție pentru ca cineva să fie membru al Bisericii, căci lipsa a trei duminici consecutive de la Dumnezeiască Liturghie este pedepsită cu caterisirea pentru clerici şi

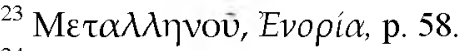

${ }^{24}$ Ibidem, pp. 133-134.

${ }^{25}$ Ibidem, p. 134.

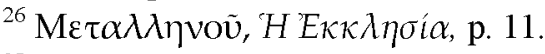

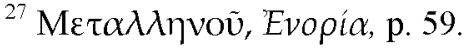


îndepărtarea de la împărtăşire pentru mireni [Canonul 80 al Sinodului Trulan sau Quinisext (691-692)] $]^{28}$.

Lucrarea lui Hristos în om, dar şi în istorie şi lume, este arătată în Dumnezeiasca Liturghie, unde Hristos este numit „doctorul sufletelor şi al trupurilor noastre". Aşadar, întreaga lucrare a lui Hristos este una de tămăduire a omului ${ }^{29}$. După Sfântul Grigorie Teologul, ,toate au fost $o$ pedagogie a lui Dumnezeu pentru noi şi vindecare a slăbiciunii noastre" $^{\text {"30. }}$. Această terapie este continuată, conform aceluiaşi Sfânt Părinte, de către episcopi, preoți şi diaconi ${ }^{31}$, fiindcă „,ceea ce se petrece în viața parohiei (viața sacramentală, asceza, faptele de filantropie şi iubire) sunt cuprinse în lucrarea de vindecare" a fiecărui credincios ${ }^{32}$. Această lucrare de vindecare este numită ,arta artelor şi ştiinţa ştiințelor”, după Sfântul Grigorie Teologul ${ }^{33}$, demonstrând şi ,,adevărata esență a teologiei ca «știință pastorală» şi simplu ca «ştiință̌ filologicoistorică, potrivit datelor academice" ${ }^{34}$.

Viața liturgică a Bisericii nu este îmbătrânită, pentru că Adevărul Hristos este mereu prezent în ea şi singurul actual ${ }^{35}$, de

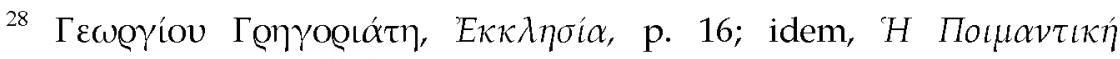

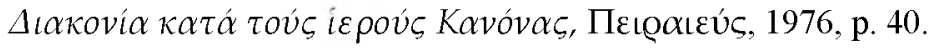

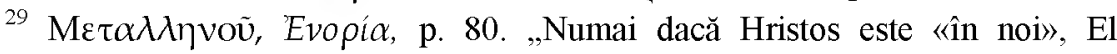
lucrează și «în mijlocul nostru». Poate să existe o adunare de oameni care foloseşte Scriptura și o cercetează (de pildă, ereticii) și, totuşi, să nu-L aibă pe Hristos. Deoarece Hristos nu există în inimile ereticilor, ci doar pe buzele lor

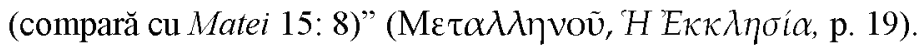

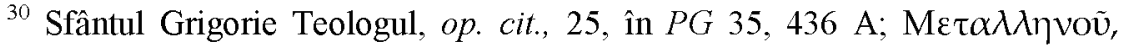
'Evopia, p. 80.

31 „Slujitori și împreună lucrători ai acestei vindecări suntem noi”, referindu-se Părintele Gheorghe Metallinos la clerici, „câți suntem întâi stătători ai

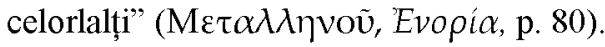

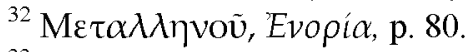

${ }^{33}$ Sfântul Grigorie Teologul, op. cit., 16, în PG 35, 425 AB.

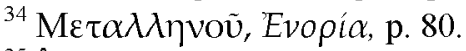

${ }^{35}$ Într-un mod arbitrar şi lipsit de obiectivitate, în Apus circulă lozinca precum că „Creștinismul a durat, a trăit 2000 de ani de la Naşterea lui Hristos până ieri””

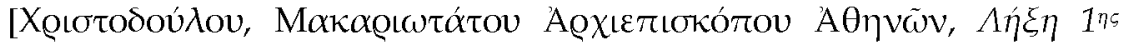


aceea, se pune problema nu a reînnoirii vieții liturgice a Bisericii, ci a vieții credincioşilor, astfel încât să fie lucrătoare în ei toate formele cultului Bisericii $^{36}$. Se doreşte, aşadar, să se ajungă la acea adunare liturgică a credincioşilor şi a clerului, prin care parohia să fie trăită ca , adunarea euharistică” a comunității bisericeşti ${ }^{37}$, adică să fie acel loc unde, după Sfântul Ioan Gură de Aur, „sunt învăţătura şi rugăciunile, unde sunt binecuvântările Părinților şi auzirea legilor dumnezeieşti, unde este adunarea fraţilor şi legătura iubirii autentice, unde este vorbirea față de Dumnezeu şi discursul lui Dumnezeu faţă de oameni" 38 . De altfel, „fiecare aspect al vieții are referință în cult şi, invers, fiecare slujbă din cult acoperă o parte a grijii de viaţă. Ceea ce se petrece cu biserica centrală a unei mănăstiri (catoliconul), se face şi cu locaşul de cult (biserica) al fiecărei parohii. De la biserică începe taina slujirii noastre personale, cu rugăciunile naşterii, îmbisericirea la patruzeci de zile, botezul, viața euharisticosacramentală, căsătoria, creşterea familiei prin înmulțirea biologică, moartea şi rugăciunile Bisericii-Parohiei după moarte" 39 .

În consecință, toate activitățile sociale şi pastorale trebuie să înceapă de la cultul Bisericii. De mult ori, însă, se întâmplă inversul, adică programarea diferitelor activităţi se face în detrimentul timpului acordat slujbelor, cu rezultatul că în loc „,să crească şi să fie zidită parohia ca biserică-trup al lui Hristos, să se ofilească şi să se

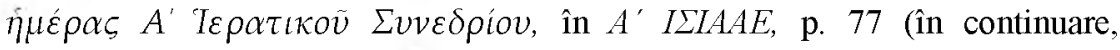

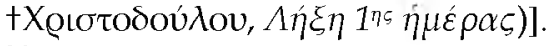

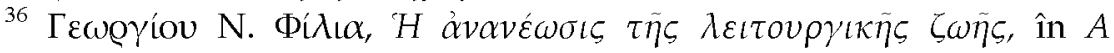

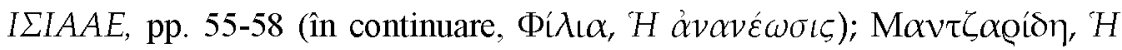

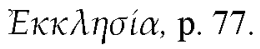

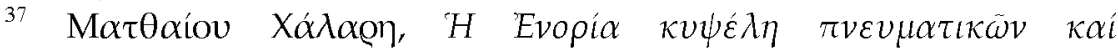
$\pi \circ \lambda \iota \tau \iota \sigma \tau \iota \kappa \tilde{\omega} v \delta \rho \alpha \sigma \tau \eta \rho \iota \tau \eta \dot{\tau} \tau \nu$, în $A^{\prime} I \Sigma I A A E$, p. 97 (în continuare,

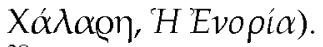

${ }^{38}$ Sfântul Ioan Gură de Aur, Cuvântul al V-lea către cei ce se adună doar la sărbători, în $P G$ 54, 669.

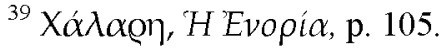


împuțineze" ${ }^{\text {"40 }}$. Un semn al secularizării parohiei, de altminteri, scandalos, este tendința unor preoți parohi, care nu pot fi numiți din această cauză păstori de suflete, de a micşora numărul şi conținutul slujbelor bisericeşti, sub diferite pretexte. Acest lucru înseamnă, pe de o parte, părăsirea vieții liturgice, iar pe de alta, ignorarea faptului că ,în [Dumnezeiasca] Liturghie şi în viaţa liturgică, viaţa şi istoria sunt transformate într-un loc şi timp al prezenței lui Dumnezeu şi al arătării lucrărilor Sale, dintre care cele mai mari sunt Sfinții şi realizările lor" ${ }^{41}$.

\section{Parohia şi societatea}

Parohia reprezintă celula vieții bisericeşti, duhovniceşti şi socialpolitice $^{42}$, adresând lumii chemarea la viața în Hristos, menită să transforme societatea din jur. Chemarea Bisericii lui Hristos către lume şi societatea sau societățile în care omul îşi duce existența efemeră nu este o invitație la însuşirea unei ideologii, ci la dobândirea unei realități vitale şi existenţiale, la „viaţa «zidirii celei noi», adică la viaţa în Hristos, prin cuvintele evanghelice: „vino şi vezi” (Ioan 2: 24). De altfel, „Biserica şi în cea mai mică unitate a ei, care este parohia din lume sau parohia monastică, este datoare să rămână o «zidire nouă», pentru ca să ofere cu adevărat viaţa harului, adică Ortodoxia"43.

În cadrul parohiei, sunt formate legăturile interpersonale întrun mod care diferă de cel al lumii seculare, aşa cum se constată din categoriile sociale fundamentale, tocmai pentru că aceste legături exprimă comuniunea şi înfrăţirea oamenilor în Hristos. De pildă,

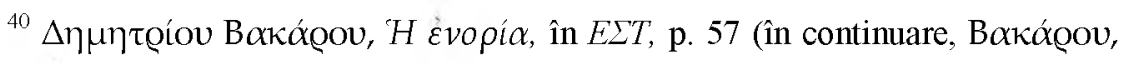
'H غ̇vopi $\alpha)$.

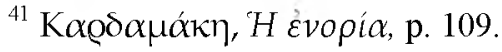

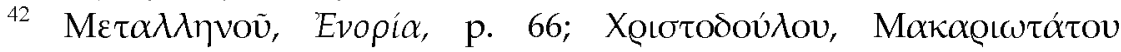

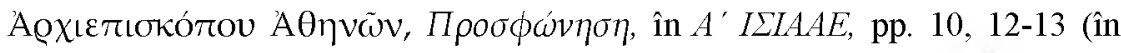

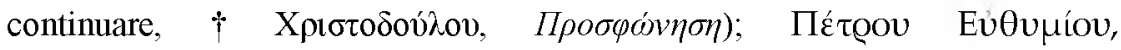
$\Pi \rho \circ \sigma \phi \omega ́ v \eta \sigma \eta$, în $A^{\prime} I \Sigma I A A E$, p. 23.

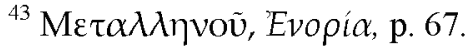


categoria de frate, pe de o parte, înseamnă cei născuți din acelaşi pântece, lucru valabil şi în lume, dar în Biserică acelaşi termen exprimă „,noua înfrățire duhovnicească, pe care o creează înfíerea în Hristos. Suntem frați în Hristos, deoarece suntem renăscuţi din acelaşi pântece duhovnicesc, din sânul Bisericii, din sfânta ei cristelniță’"44; problemele economice sunt trăite la nivelul parohiei prin actele de filantropie creştină, iar dacă viața este autentică într-o parohie, atunci se poate ajunge la practica în Duhul Sfânt a comunității din Ierusalim, când toate bunurile erau în comun (Fapte 2: 45). Dacă un asemenea mod de viață nu se mai realizează la nivelul parohiei din lume, dar este continuat în ,parohia monastică”, acest lucru se datorează faptului că parohia din lume „este limitată la sfera religios-latreutică şi nu îmbrățişează toată viața comunităţii" "45, ştiința devine în cadrul vieții din parohie „mărturie profetică, ca o palpare permanentă a energiilor necreate ale lui Dumnezeu în natură şi vestire a minunilor lui Dumnezeu în lume" ${ }^{\text {"46; }}$; erosul este recunoscut ca element de formare al familiei, dar capătă şi un caracter de taină, pentru că este sfințit şi integrat în planul mântuirii şi lupta duhovnicească ${ }^{47}$; politica dobândeşte un caracter sacerdotal şi de slujire, fiindcă atunci „când politicienii trăiesc ca creştini, de la comunitate până la stat, vor acționa ca membrii ai trupului bisericesc, pentru reglementarea problemelor şi nevoilor material-vitale ale acestui trup, în colaborare cu slujitorii aspectului duhovnicesc al vieții, adică cu clericii” ${ }^{\prime 4}$.

Prin urmare, preotul „este dator să poată surprinde esența politicii şi a schimbărilor ei, fluctuațiile vieții economice, condițiile de supraviețuire, problemele familiei, pentru ca să-şi poată îndruma corect fiul duhovnicesc, remarcând rădăcinile problemelor duhovniceşti şi nu simptomele" ${ }^{\text {"49 }}$, cu scopul vădit de a-l conduce la

\footnotetext{
${ }^{44}$ Ibidem, p. 61.

${ }^{45}$ Ibidem, p. 64.

${ }^{46}$ Ibidem.

${ }^{47}$ Ibidem, p. 65.

${ }^{48}$ Ibidem.

${ }^{49}$ Ibidem, p. 88.
} 
vindecare. Legătura clerului cu credincioşii trebuie să-i conducă la reconsiderarea problemelor lor în Hristos, deoarece conținutul creştin al cerințelor sociale nu se identifică cu sensul celor percepute într-o lume fără de Hristos. Slujirea socială nu este limitată doar la aspectul orizontal al vieții, ci are ca țintă conducerea omului spre îndumnezeire. $\mathrm{Cu}$ alte cuvinte, omul este chemat să nu piardă ,perspectiva sa

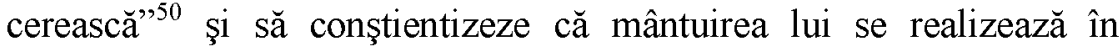
societatea în care trăieşte, adică în comuniunea de iubire cu cei din jurul său ${ }^{51}$. De aceea, sociabilitatea şi spiritualitatea, prin ultima înțelegându-se viața duhovnicească, se cade să păşească împreună ${ }^{52}$.

Parohia comunică cu lumea, iar membrii ei se mişcă în societatea în care trăiesc şi care depăşeşte limitele administrative ale parohiei, ceea ce înseamnă că viaţa şi activitățile parohiei nu pot să fie limitate la zidurile locaşului de cult, ci se extind în întreaga societate $^{53}$. De altfel, parohia este chemată să-i ajute pe credincioşi în a realiza depăşirea unei vieți impersonale şi de masă şi a regăsi spiritualitatea şi deplinătatea socială prin viaţa în Hristos, care înseamnă şi dezvoltarea relaţiilor interpersonale ${ }^{54}$. Acest lucru impune şi depăşirea unei situații de lâncezeală din partea creştinilor care sunt doar botezați, adică morți duhovniceşte, şi s-au transformat, cei mai mulți dintre ei, în creştini ai marilor sărbători şi ai diferitelor întruniri ocazionale (botez, căsătorie etc.) ${ }^{55}$.

De dorit este ca parohia să nu ajungă „o prezență formală a oamenilor în Biserică, în timpul adunării latreutice, fără o

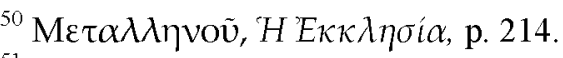

${ }^{51}$ Ibidem, p. 215.

${ }^{52}$ Ibidem, p. 216.
}

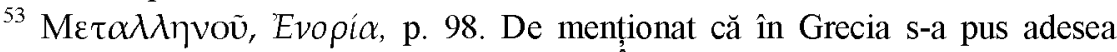
problema despărțirii dintre Stat și Biserică. Însă, cei mai mulți teologi şi clerici acuză această tendinţă ca pe o luptă împotriva Tradiției ortodoxe şi limitarea parohiei la o comunitate închisă, aşa cum s-a petrecut în fostele țări comuniste

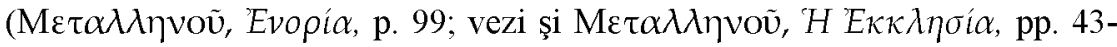
72).

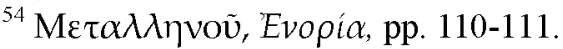

${ }^{55}$ Ibidem, p. 111.
} 
substanțială participare de comuniune şi comunitară a credincioşilor la cele se săvârşesc" ", , după cum nici „o autoritate birocratică religioasă sau o fundație de deservire doar a nevoilor religioase ale unor indivizi religioşi, ci centrul de unitate şi de comuniune al tuturor enoriaşilor şi al transformării depline a vieții lor, a legăturilor şi a lumii lor în «Împărăţia lui Dumnezeu»",57.

Cât priveşte relația parohiei cu autoritățile civile şi politice locale, se recomandă urmarea exemplului legăturii dintre Biserică şi stat în cadrul teologiei şi tradiției patristice, conturată pe baza cuvintelor lui Hristos şi a experiențelor Sfinților Părinți. Autoritatea politică este lăsată de Dumnezeu şi reprezintă „lucrarea înțelepciunii” Sale ${ }^{58}$, observă Sfântul Isidor Pelusiotul, ,pentru ca lumea să nu cadă în necuviință"59. Supunerea pe care o cere Sfântul Apostol Pavel (Rom. 13: 1) față de „stăpâniri”, arată că existența puterii politice este necesară pentru a se asigura armonia societății, înrobită căderii şi păcatului ${ }^{60}$. Referitor, însă, la istoria Imperiului bizantin, prin transformarea adusă puterii politice de către Sfântul Împărat Constantin cel Mare, corect este să se vorbească, conform Părintelui Gheorghe Metallinos, nu despre legătura dintre Biserică şi stat, ci dintre preoție şi împărăție, din moment ce nu exista două trupuri, un trup al puterii politice şi un altul al Bisericii, ci unul şi acelaşi trup, care este Trupul lui Hristos, al cărui Cap este doar El, iar conducătorii politici şi duhovniceşti sunt slujitorii Săi şi ai aceluiaşi popor al Imperiului, care era, în acelaşi timp, poporul statului, dar şi poporul Bisericii. Aşadar, „întregul Imperiu era Biserica, adică Trupul lui Hristos, comuniunea creştinilor ortodocşi cu Hristos şi între ei" ${ }^{\prime \prime}$. De aceea, conducătorul politic desfăşoară şi el o lucrare „pastorală”, dar în cadrul vieții sociale şi cu ajutorul legilor civile,

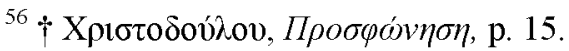

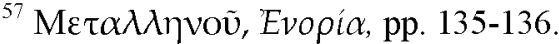

${ }^{58}$ Sfântul Isidor Pelusiotul, op. cit., Cartea a II-a, Epistola a CCXVI-a, în PG $78,657 \mathrm{D}-660 \mathrm{~A}$.

${ }^{59}$ Ibidem, $660 \mathrm{~B}$.

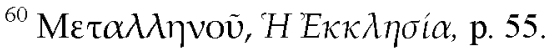

${ }^{61}$ Ibidem, p. 57.
} 
care se cuvine să fie conforme voinței lui Dumnezeu, aşa cum este exprimată de către Ortodoxie. În mod contrar, ,politicianul devine eretic, iar politica erezie, când prin legile neortodoxe, adică antiortodoxe, este creat un cadru de viață care nu conduce la mântuire, ci la pierzanie" ${ }^{\prime 2}$.

În societatea românească, precum şi în cea grecească, a fost menţinută această legătură a slujirilor şi la nivelul parohiei, din moment ce întreaga viață a comunității se desfăşoară în trupul bisericesc, adică în parohia care se identifică limitativ cu comunitatea respectivă. "Conducătorii politici ai tuturor treptelor", în societăţile majoritar formate din creştini ortodocşi, ,sunt percepuţi până astăzi, în mod bisericesc, ca slujitorii poporului lui Dumnezeu, care îşi preiau slujirea lor cu binecuvântarea şi harul dumnezeiesc", avându-se în vedere jurământul pe care îl fac şi slujbele de binecuvântare ${ }^{63}$. În practică, din nefericire, se întâlneşte şi situația în care conducătorii politici şi întâistătătorii comunităților, care ar trebui să fie cei dintâi prezenți la adunarea euharistică, dacă nu sunt adversari ai Bisericii, cel puţin sunt indiferenți ${ }^{64}$. „De aceea şi poporul credincios pretinde -şi are dreptul să pretindă- de la politicienii lui consecvență şi regim ortodoxe" ${ }^{\prime 65}$.

\section{Legătura vie dintre învățătura Bisericii şi practica pastorală}

Parohia reprezintă un trup euharistic, dar şi social, pentru care se pretinde o bună organizare, astfel încât învățătura Bisericii să devină practică pastorală. În acest exercițiu, preotul are meritul de a implica pe toți membrii parohiei în activităţile pastorale, care se pot împărți pe mai multe sectoare: 1) catehizarea, care este „absolut necesară după Botez, pentru menținerea credinciosului în Trupul

\footnotetext{
${ }^{62}$ Ibidem, p. 64.

${ }^{63}$ Ibidem, pp. 67-68.

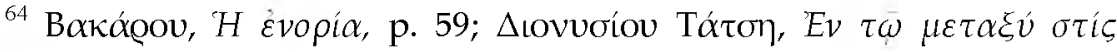
" $\alpha \kappa \rho \varepsilon \zeta " \ldots$, în $E \Sigma T$, p. 189.

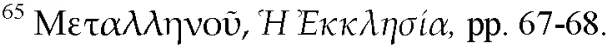


Bisericii”66, 2) grija de cei suferinzi, prin înființarea de cantine, internate, case de bătrâni; 3 ) preocuparea față de tineret, instituinduse centre de tineret, locuri de joacă etc.

Pe baza convingerii că regăsirea continuității tradiției sfântpatristice, cu ajutorul Sfinților Colivari, considerați apropiaţi grecilor contemporani ca timp şi limbaj, poate să ajute la renaşterea spirituală ${ }^{67}$, programul liturgic din parohiile greceşti este axat pe săvârşirea cât mai deasă a Dumnezeieştii Liturghii şi împărtăşirea credincioşilor cât mai des cu putință. De altfel, figurile Sfinților Colivari Nicodim Aghioritul, Macarie al Corintului şi Atanasie de Paros, precum şi cea a lui Neofit Kavsokalivitul, au lăsat un model al reînnoirii liturgice şi reprezintă ,avangarde ale fiecărei problematizări contemporane" privind acest aspect ${ }^{68}$.

Reînnoirea liturgică nu priveşte, aşa cum s-a subliniat şi mai sus, schimbarea cultului, ci îmbunătățirea vieții credincioşilor, prin mai multe fapte, unul dintre ele fiind ,învățătura liturgică”, adică „înțelegerea şi trăirea cultului”. $\mathrm{Cu}$ alte cuvinte, este nevoie ca credincioşii să aibă parte de o „educaţie liturgică”, fiindcă „nu poate să existe o reînnoire liturgică, dacă nu există o educație liturgică"69. Pe baza acestei considerații, este nevoie nu doar de catehizarea celor mici, ci şi a celor mari, nu prin predici ,insipide, serbede, lipsite de conținut, fără de gust, moralizatoare", ci prin cateheză pentru credincioşi $^{70}$ şi seminarii speciale pentru clerici ${ }^{71}$. Este vorba despre

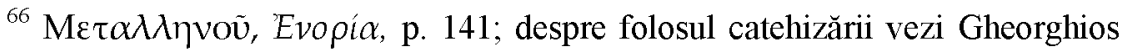
Kapsanis, Egumenul Sf. Mănăstiri a Cuviosului Grigorie, Probleme de eclesiologie şi pastorație, traducere din limba greacă de Nicuşor Deciu, București, Editura Anestis, 2015, pp. 135-159.

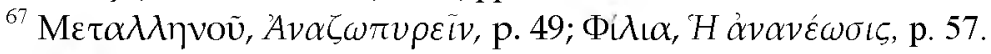

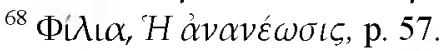

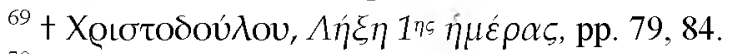

${ }^{70}$ Ibidem, pp. 79-80.

${ }^{71}$ Ibidem, p. 82. Vrednicul de pomenire Hristodul, arhiepiscopul Bisericii Ortodoxe din Grecia, punând problema reînnoirii religioase şi a educaţiei liturgice, a fondat Comisia Sinodală Specială de Reînnoire Liturgică, formată din cei mai buni specialişti în domeniu, fie ei clerici sau mireni $(\dagger$ 
lucrarea catehetică a Bisericii, cu alte cuvinte, despre Catehezele mistagogice, care urmau imediat după primirea Sfintei Taine a Botezului. Acest fapt ilustrează vechimea pe care o aveau Catehezele respective în lucrarea de mântuire a credincioşilor ${ }^{72}$. Din această perspectivă, reînnoirea liturgică reprezintă „o misiune foarte importantă" a Bisericii, pentru ca parohia să fie ,un centru de cult, un centru de viață duhovnicească”, deoarece „viața duhovnicească se dezvoltă în cult"73.

Toate slujbele ciclului liturgic zilnic au ca centru Dumnezeiasca Liturghie, dar şi Sfintele Taine se cuvine să fie unite cu Dumnezeiasca Liturghie, după cum era în vechime practica liturgică a Biserici ${ }^{74}$. De altfel, în teologia euharistică a Bisericii nu tendinţa spre Dumnezeiasca Împărtăşire rară este subliniată, ci participarea credincioşilor, cu pregătirea necesară, la „Potirul Vieții”, pentru că ,în teologia euharistică coexistă «arpopiați-vă» cu premisele «frică de Dumnezeu», «credință» şi «dragoste»»"75. Grija pastorală este lupta pentru redobândirea apropierii regulate a credincioşilor de Dumnezeiasca Împărtăşire ${ }^{76}$, căci „reînnoirea liturgică cât priveşte participarea credincioşilor la Dumnezeiasca Euharistie se va realiza doar prin intermediul participării mai active la Dumnezeiasca Împărtăşanie" ${ }^{\text {"77 }}$.

Din acest fapt decurge perceperea parohiei ca Biserica în miniatură, dar întreagă, nu o parte, ca celula vitală a Bisericii, ca locul şi timpul euharistic de transformare a lumii în Hristos, ca

X arhiepiscop, a slujirii în limba vorbită a grecilor, dar această încercare a lui s-a lovit de conservatorismul cercurilor bisericești din Grecia, vezi I. M. Croitoru, Tradiția printre tradiții, în Omagiu profesorului Nicolae V. Dură la 60 de ani, Constanța, Editura Arhiepiscopiei Tomisului, 2006, pp. 466-471.

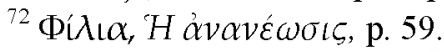

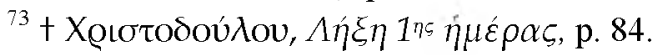

${ }^{74} \Phi \grave{\lambda} \iota \alpha, H \dot{\alpha} v \alpha v \varepsilon \dot{\varepsilon} \omega \sigma \iota$, pp. 61-62

${ }^{75}$ Ibidem, p. 64.

${ }^{76}$ Ibidem.

${ }^{77}$ Ibidem, p. 66. 
fractalul ${ }^{78}$ vieții monahale de obşte. Această reconsiderare a parohiei proiectează dimensiunea ei în toate aspectele societății umane, astfel că „viața parohiei poate să dea o dimensiune preoțească politicii, un duh profetic ştiinței, o faţă umană legăturile personale şi un caracter sacramental iubirii" 79 .

Viaţa parohiei înseamnă o combinare a slujirii cultice cu cea a slujirii sociale, pentru a fi evitată, pe de o parte, transformarea parohiei într-o corporație, dacă se va sublinia doar partea socială, iar pe de altă parte, limitarea parohiei doar la o practică liturgică de tipic. Accentuarea unui caz sau a celuilalt face ca parohia să fie „condamnată să eşueze" de la scopul ei şi să-şi frângă firea ei divinoumană în două părți: în partea dumnezeiască, pe care o consideră ca pe o supraevaluare, şi în partea omenească, pe care o abordează în mod disprețuitor ca pe o lipsă de valoare ${ }^{80}$. Fără această dublă raportare a parohiei, adică la realitatea vieții duhovniceşti conjugată cu nevoile confraţilor, parohia riscă să se transforme ,într-un loc al întâlnirilor sociale de tip religios" ${ }^{\prime 2}$. Parohia şi locaşul de cult are menirea să transforme lumea şi să ierarhizeze valorile, iar firele care ,tes haina comportamentului bisericesc" sunt iubirea, comuniunea, înflăcărarea inimilor, darea mâinilor, îmbrățişarea sau sărutul păcii ${ }^{82}$.

Funcțiunea parohiei este să devină asemenea unui „stup de activităti" duhovniceşti, culturale şi sociale ${ }^{83}$, ceea ce se urmăreşte cu multă insistență în Biserica Ortodoxă din Grecia. Găsesc de cuviință ca în acest punct final al studiului meu să prezint funcțiunea unei parohii din capitala Greciei, Atena, unde am avut privilegiul să locuiesc aproximativ 15 ani (1996-2011). Mă voi referi la parohia

\footnotetext{
${ }^{78}$ Introdus de către matematicianul Benoît Mandelbort, în 1975, acest termen indică o formă geometrică neregulată care poate să fie divizată în părți, astfel încât fiecare dintre ele să fie o copie miniaturală a întregului. Modelul generat pe calculator de către Mandelbort a fost numit „amprenta lui Dumnezeu”.

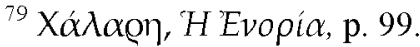

${ }^{80}$ Ibidem, p. 100.

${ }^{81}$ Ibidem, p. 106.

${ }^{82}$ Ibidem.

${ }^{83}$ Ibidem, p. 110.
} 
"Sfânta Marina", din cartierul Ano Ilisa, unde preot paroh este Părintele Constantin Karaisaridis, vorbitor de limbă română şi având conştiință ortodoxă, nu naţionalistă.

Piatra de temelie a fost pusă în anul 1976, iar înălțarea locaşului de cult, conceput pe două nivele, a durat, într-o primă fază, până în anul 1987, când a avut loc sfințirea primului locaş de cult ( 9 noiembrie 1987), care reprezintă parterul şi este închinat Sfântului Nectarie (9 noiembrie). Cel de al doilea locaş de cult, fiind la etajul întâi şi închinat Sfintei Marina (17 iulie), a fost sfințit la 17 octombrie 1998. Am avut ocazia să vizitez această parohie în anul 1991, când eram student la Facultatea de Teologie din Bucureşti şi, ca vice-preşedinte al Ligii Tineretului Ortodox Român, am luat parte la un pelerinaj în Grecia, prin grija Părintelui Profesor Ioan Buga. În timpul acelei vizite, Părintele Constantin ne-a prezentat cele două locaşuri şi în cel de la etaj se montase candelabrul. Când am revenit pentru studii la Atena, în ianuarie 1996, am reluat legătura cu Părintele Constantin şi am observat că nu erau terminate lucrările de împodobire ale celor două locaşuri (pictură, mobilier, exterior etc.). Am înțeles de la Părintele Constantin, văzându-mi nedumerirea, că grija preoților a fost prioritară pentru zidirea duhovnicească a noii parohii şi nu pentru împodobirea zidurilor.

Aşadar, parohia avea un program pastoral şi duhovnicesc bine stabilit, în care implicați erau nu doar preoții, ci membrii celor două Comitete, cel parohial şi cel de femei, apoi foarte mult tineret. Concomitent cu zidirea celor două locaşuri de cult a fost începută zidirea unui Azil pentru vârstnicii parohiei şi a fost dobândit un apartament cu trei camere, unde erau găzduiți studenți la Facultatea de Teologie din Atena, beneficiind şi eu de o cameră în acest mic internat parohial. După terminarea lucrărilor de împodobire a celor două locaşuri, am observat că unul dintre scopurile parohiei a fost să dobândească o clădire, care este numită „Centru Duhovnicesc”. Multe alte parohii din Atena şi chiar pretutindeni în Grecia au asemenea Centre, unde sunt desfăşurate diferite activitătii culturale şi de catehizare a tinerilor. Până la dobândirea acestui Centru, catehizarea se făcea în cele două locaşuri de cult, după săvârşirea 
Dumnezeieştii Liturghii, copiii şi tinerii fiind împărtitị pe vârste şi sex, doar între clasele a V-a şi a IX-a de Gimnaziu ${ }^{84}$. Cei mai mai mari sunt cateheții celor mai mici, iar pentru cei mari preoții şi adulții cu râvna vieții duhovniceşti. Cateheza durează aproximativ o oră, între orele 11:00-12:00, timp în care părinţii copiilor sunt adunați în jurul preotului paroh, care fie le rosteşte o cateheză, fie le explică anumit aspecte din pericopa Evangheliei sau a Apostolului din duminica respectivă. Niciodată nu am observat ca să fie rânduită săvârşirea vreunui slujbe în acest interval de timp. Toate Sfintele Taine sunt programate după orele 14:00, tocmai pentru ca preoții să aibă timp de discuții cu credincioşii, dar şi credincioşii între ei. De altfel, Comitetul de femei strânge, după rostirea rugăciunii Tatăl nostru, sumele pe care credincioşii le donează, trecând cu un coşuleț prin fața lor, iar din aceste sume sunt cumpărate dulciuri, cafea şi băuturi răcoritoare, care sunt oferite la ieşirea din locaş, fie într-o sală specială, fie în pridvor, astfel încât comuniunea trăită în timpul Dumnezeieştii Liturghii să fie continuată. De asemenea, celor care urmează Şcoala catehetică le sunt oferite gustări şi băuturi răcoritoate.

Grija pentru tineretul parohiei nu se limitează doar la catehizare, ci în fiecare vară sunt create tabere, unde participă copiii şi tinerii parohiei, împărțiți pe vârste, timp de 10-14 zile. Fiecare Mitropolie are mai multe locuri de tabără, pe care le pune la dispoziția parohiilor, dar, în ultimul timp, chiar parohiile au dobândit locuri proprii de tabără. Parohia „Sfânta Marina” are un asemenea loc în insula Evia, într-un cadru natural, astfel încât tineretul să se bucure de întâlnirea cu natura şi beneficiile băilor în mare.

În atenţia tinerilor este pusă şi organizarea de serbări, cel puțin de trei ori pe an, la Naşterea Domnului, la Învierea Domnului şi la încheierea anului şcolar şi universitar, când, de obicei, este

${ }^{84}$ Grupele sunt următoarele: 1) preșcolarii; 2) clasele I şi a II-a de la ciclul primar; 3) clasele a III-a şi a IV-a de la acelaşi ciclu; 4) clasele a V-a și a VI-a de la Gimnaziu, băieți și fete separat; 5) clasele a VII-a, a VIII-a şi a IX-a de la același ciclu, băieți şi fete separat; 6) clasele a X-a, a XI-a şi a XII-a de Liceu. În Grecia, ciclul primar şi Gimnaziul durează 9 ani, iar Liceul 3 ani. 
prezentată o piesă de teatru, cu temă religioasă sau patriotică, artiştii fiind chiar elevii Şcolii catehetice. Pe de altă parte, există o legătură strânsă între parohie şi şcolile existente în cadrul parohiei sau în împrejurimi. Preoții merg în şcoli ca să-i spovedească pe elevi, în locuri special amenajate, iar în timpul perioadelor de post am fost martor când elevii unei şcoli întregi veneau să se împărtăşească într-o anume zi, când era săvârşită special pentru ei Dumnezeiasca Liturghie. Uneori, reprezentanţii elevilor şi ai profesorilor aduceau şi artose pentru săvârşirea Litiei.

Problemele şi cazurile sociale ale parohiei sunt cunoscute de către preoții parohiei prin buna lor organizare administrativă. Comitetul parohial ia parte activă la acțiunile de filantropie, dăruindu-se celor în cauză alimente, îmbrăcăminte şi sume de bani (pentru plătirea curentului, a apei etc.), toate acestea fiind donații ale credincioşilor, făcute de-a lungul anului bisericesc. Unele parohii au Cantine, unde este oferită mâncare caldă, având chiar şi Azile pentru cei în vârstă. Parohia „Sfânta Marina” dispune şi ea, aşa cum am precizat mai sus, de un asemenea Azil. Cei bolnavi sunt vizitați la casele lor sau la spital, iar nevoile de transfuzii de sânge sunt asigurate chiar de către credincioşii parohiei, căci anual se organizează donarea de sânge, astfel încât fiecare parohie are propria bancă de sânge.

Eliberarea certificatului de căsătorie are valoare recunoscută de către stat, dar se pune accent pe pregătirea celor care vin să primească Sfânta Taină a Căsătoriei, precum şi pe cea a Botezului. $\mathrm{Au}$ loc întâlniri repetate, pentru catehizarea celor implicați.

Multe dintre parohii au şi buletin propriu de informare a credincioşilor sau chiar reviste, având caracter ştiinţific. Revista parohiei Sfânta Maria se numeşte Invăţătură şi Inş̧iinţare ( $\Delta \iota \delta \alpha \chi \eta ்$

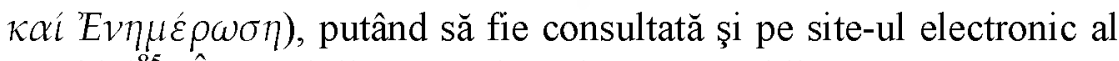
parohiei $^{85}$. In paginile acestei reviste am publicat o prezentare a

${ }^{85}$ Vezi http://www.agiamarinailision.gr/didaxi, 20.04.2015. 
Părintelui Arsenie Papacioc şi a învățăturilor sale ${ }^{86}$, susținută în cadrul Școlii părinților. La nivelul fiecărei parohii există organizarea acestei Şcoli, cu un program de întâlnire săptămânală sau lunară, după caz, unde sunt chemaţi diferiți duhovnici, profesori şi oameni de cultură, pentru a fi dezbătute diferite teme duhovniceşti sau de actualitate socială. De altfel, odată cu începerea anului universitar, în fiecare parohie sunt reluate activităţile săptămânale. Spre exemplu, în cadrul parohiei Sfânta Marina se desfăşoară Şcoala de Muzică bizantină, pe care am frecventat-o şi eu. Programul ei este luni şi marți seara, iar dacă sunt mai mulți doritori se extinde şi pentru miercuri seara. Alături de această Şcoală mai funcționează şi cea de Artă bizantină, unde se învață pictarea de icoane, având programul într-una din serile săptămânii, stabilit de comun acord cu cei ce o frecventează. Nu exagerez, dar am întâlnit mulți greci care nutresc dorință să aibă în casele lor icoanele pictate chiar de ei înşişi, iar duminica la strană se formează adevărate coruri prin numărul celor care participă la cântare. Învăţarea muzicii bizantine sau deprinderea artei de a picta icoane reprezintă reacții la occidentalizarea şi secularizarea societăţii greceşti ${ }^{87}$. Luni seara, după programul Școlii de muzică bizantină, se desfăşoară întâlnirea cu tinerii, discutându-se diferite teme. Miercuri seara, întâlnirea cu femeile din parohie, unde un rol deosebit îl au preotesele. Joi seara, întâlnirea cu cei căsătoriți. Vineri seara, întâlnirea cu cei în vârstă. Fiecare preot are o zi anume când spovedeşte, acordându-se fiecărui credincios timpul de care are nevoie. De multe ori, am aşteptat timp îndelungat ca să-mi vină rândul la scaunul spovedaniei şi nu am observat niciodată grabă din partea Părintelui Constantin sau nemulțumiri venite de la credincioşi.

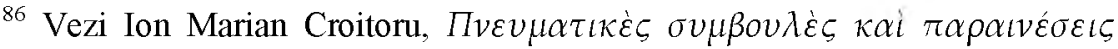

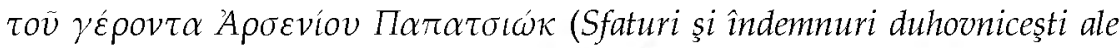

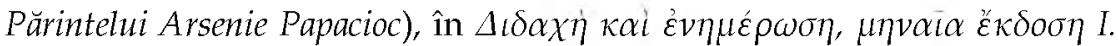

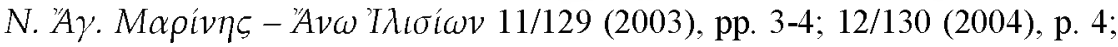
13/131 (2004), p. 4; 13/132 (2004), p. 4; 13/133 (2004), pp. 3-5; 13/134 (2004), p. $4 ; 13 / 135$ (2004), pp. 4-6; 14/136 (2005), pp. 3-4; 14/138 (2005), pp. 3-4.

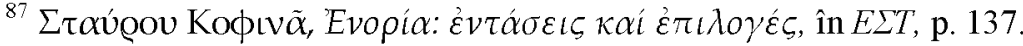


Programul liturgic nu este limitat doar la săvârşirea slujbelor caracteristice în zile de sărbătoare şi duminici, ci zilnic sunt programate slujbe din ciclul liturgic, mai ales săvârşirea vecerniilor, marți şi joi seara, apoi a Dumnezeieştii Liturghii în zilele de miercuri şi vineri, la orele dimineții, astfel încât să ia parte şi cei ce merg la lucru. Diversitatea programului liturgic este posibilă datorită faptului că în parohia respectivă slujesc patru preoți, la care se adaugă şi cei pensionari, fie că au slujit în parohie, fie că locuiesc în perimetrul parohiei respective. Pentru cinstirea unor Sfinți sunt organizate privegherii de noapte, cu săvârşirea Dumnezeieştii Liturghii. Am observat că în parohiile în care a fost cultivată deasa Dumnezeiasca Impărtăş̧anie, credincioşii nu sunt doar cei în vârstă, ci şi mulţi tineri, crescuți în atmosfera duhovnicească a împărtăşirii lor continue din pruncie.

Încă un amănunt, am întâlnit în Atena, dar şi în Pireu, parohii care a făcut misiune în Africa, zidind pentru localnicii de acolo, fie ei creştini ortodocşi sau de alte convingeri religioase, şcoli şi biserici, făcându-le şi fântâni.

Sunt de părere că ar merita cultivat un schimb permanent de experienţă între slujitorii Bisericii Ortodoxe din Grecia şi cei ai Bisericii Ortodoxe din România, iar legăturile dintre clericii şi slujitorii celor două Biserici ar merita să fie mult mai strânse, astfel încât noi, românii, să luăm din conştiința şi zelul preoțesc al grecilor, iar ei, la rândul lor, să ia din evlavia românilor.

\section{Bibliografie}

1. Benga, Daniel, Familia preotului, aspecte teologice, canonice şi pastoralmisionare, în „Glasul Bisericii”, LVII, nr. 9-12, sept.-dec. 2002, pp. 64-79.

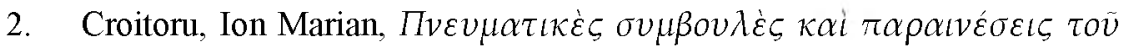

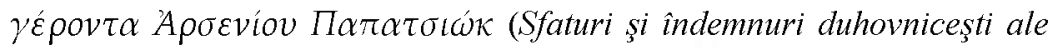

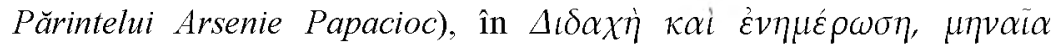

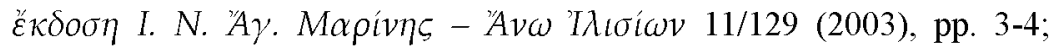
$12 / 130$ (2004), p. 4; $13 / 131$ (2004), p. 4; 13/132 (2004), p. 4; 13/133 (2004), pp. 3-5; 13/134 (2004), p. 4; 13/135 (2004), pp. 4-6; 14/136 (2005), pp. 3-4; 14/138 (2005), pp. 3-4. 
3. Idem, Tradiția printre tradiții, în Omagiu profesorului Nicolae V. Dură la 60 de ani, Constanța, Editura Arhiepiscopiei Tomisului, 2006, pp. 466-471.

4. Faros, Filotheos, Clerul azi - o privire din interior, tentantii, impasuri, maladii şi remedii, traducere din limba greacă de Lăzărescu Ovidiu, Galați, Editura Egumenița, 2013.

5. Ierotei Vlahos, Mitropolit de Nafpaktos, Monahismul ortodox ca viață profetică, apostolică şi martirică, traducere de monahul Calist, Craiova, Editura Mitropolia Olteniei, 2005.

6. Kapsanis, Arhim. Gheorghios Egumenul Sf. Mănăstiri a Cuviosului Grigorie, Probleme de eclesiologie şi pastorație, traducere din limba greacă de Nicușor Deciu, București, Editura Anestis, 2015.

7. Necula, Nicolae D., Parohia - spațiu de activitate pastoral-misionară a preotului, în „Glasul Bisericii”, LVII, nr. 1-4, ian.-apri. 2001, pp. 60-76.

8. Patrologiae cursus completus, Series Graeca, ed. J. - P. Migne, Paris, 1857-1866 (în continuare, $P G$ ).

9. Romanidis, Ioan, Teologia patristică, trad. din limba greacă, note, completări bibliografice şi postfaţă de Ion Marian Croitoru, Târgovişte, Editura Bibliotheca, 2012.

10. Sfântul Grigorie Teologul, Cuvântul al II-lea apologetic din cauza fugii în Pont, în $P G 35,407$ A -514 C.

11. Sfântul Ignatie, Epistola către smirneni, în $P G 5,707$ A - 718 C.

12. Sfântul Ioan Gură de Aur, Cuvântul al V-lea către cei ce se adună doar la sărbători, în $P G$ 54, 669-674.

13. Idem, Omilia a II-a la Epistola a II-a către Timotei, în $P G$ 62, 605-614.

14. Idem, Omilia a XI-a la Faptele Apostolilor, în $P G$ 60, 93-100.

15. Idem, Omilia a XV-a la Evanghelia după Ioan, în $P G$ 59, 97-102.

16. Idem, Omilia a XVIII-a la Epistola a II-a către Corinteni, în $P G$ 61, 523-530.

17. Idem. Omilia a LXXXVI-a la Evanghelia după Ioan, în $P G$ 59, 467-474.

18. Idem, Omilie la Înălțarea Domnuhui nostru Iisus Hristos, în $P G$ 52, 773-792.

19. Sfântul Isidor Pelusiotul, Epistolar, Cartea I, Epistola a XXXII-a, în PG 78, $201 \mathrm{BC}$.

20. Idem, Epistolar, Cartea a II-a, Epistola a CCXVI-a, în PG 78, 657 C $660 \mathrm{~B}$.

21. Idem, Epistolar, Cartea a III-a, Epistola a CCXXIII-a, PG 78, 905-908.

****

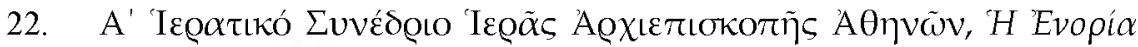

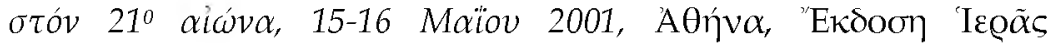

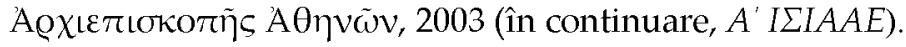




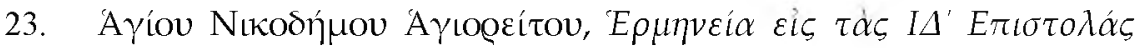

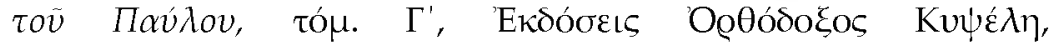

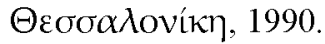

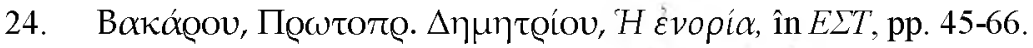

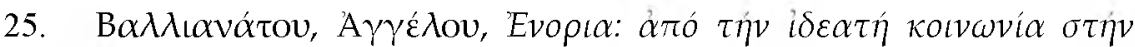
$\alpha \lambda \eta \theta t v \eta$ în $E \Sigma T$, p. 81-94.

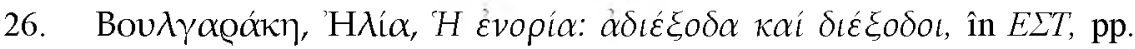
29-44.

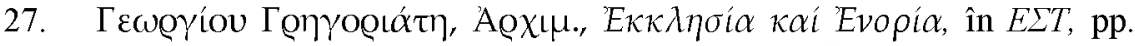
11-27.

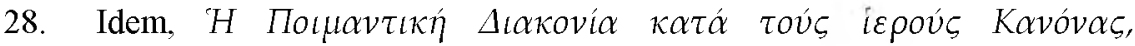

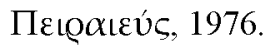

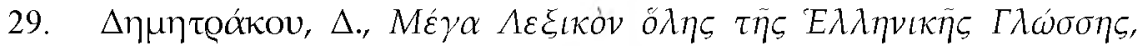

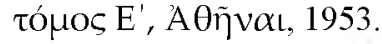

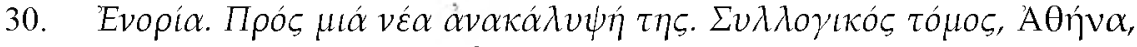

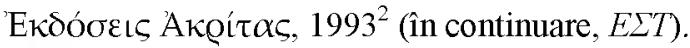

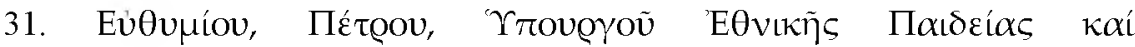

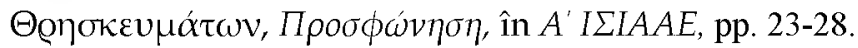

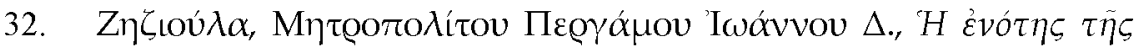

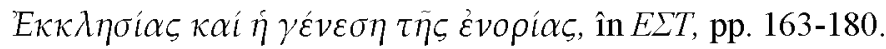

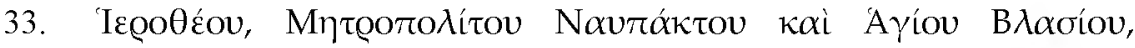

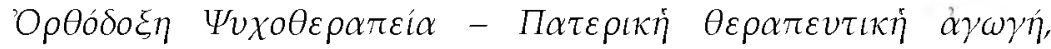
$\Lambda \iota \beta \alpha \delta \varepsilon \iota \alpha \alpha, 2000^{7}$.

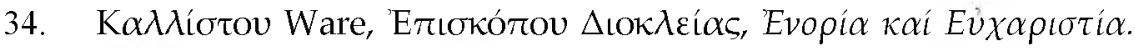

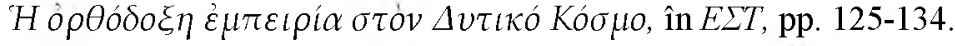

35. К К

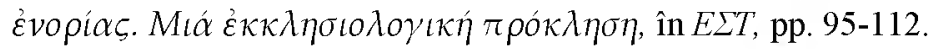

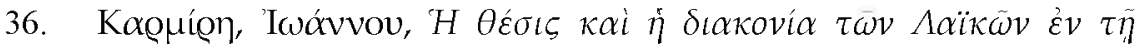

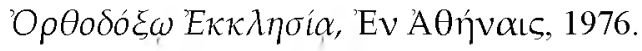

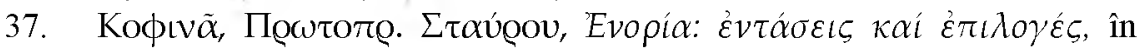
E2T, pp. 135-162.

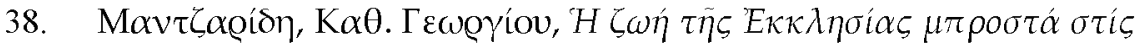

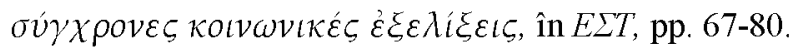

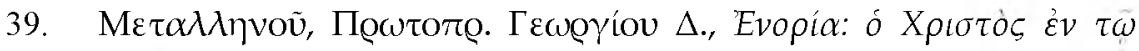

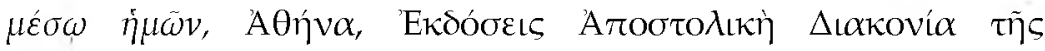




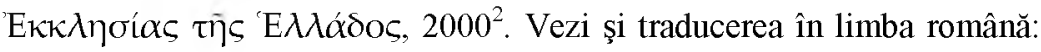
Gheorghios D. Metallinos, Parohia - Hristos in mijlocul nostru, trad. de pr. prof. Ioan I. Ică, Sibiu, Editura Deisis, 2004.

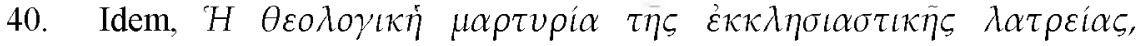

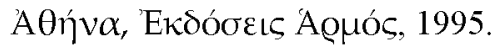

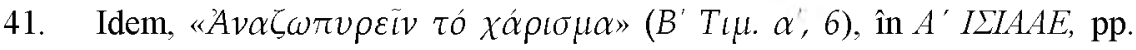
33-53.

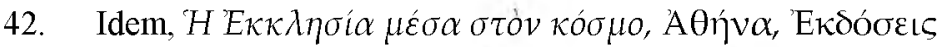
А

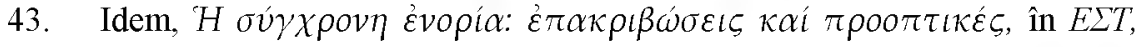
pp. 113-124.

44. $\Sigma \tau \alpha$

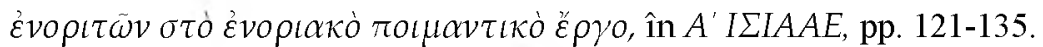

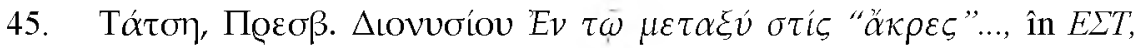
pp. 181-201.

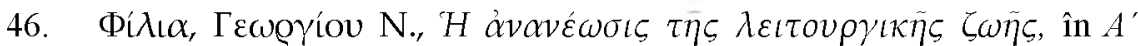
IIIAAE, pp. 55-70.

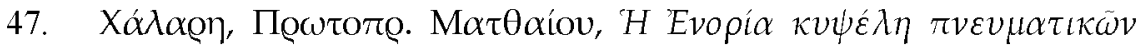

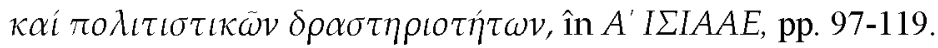

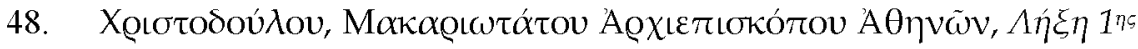

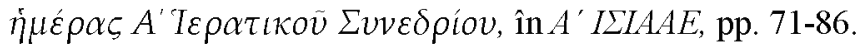

49. Idem, $\Lambda \bar{\eta} \xi \eta A^{\prime} T \varepsilon \rho \alpha \tau \iota k o \bar{v} \Sigma v v \varepsilon \delta \rho i o v$, în $A^{\prime} I \Sigma L A A E$, pp. 137-160.

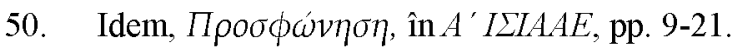

